\title{
Video v učitelském vzdělávání: přístupy a výzvy ${ }^{\mathbf{1}}$
}

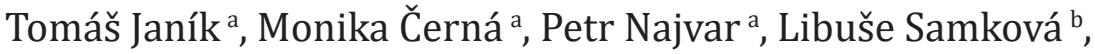 \\ Lukáš Rokos ${ }^{\mathrm{b}}$, Jan Petr ${ }^{\mathrm{c}}$
}

\footnotetext{
a Masarykova univerzita, Pedagogická fakulta, Institut výzkumu školního vzdělávání b Jihočeská univerzita v Českých Budějovicích, Pedagogická fakulta, Katedra matematiky c Jihočeská univerzita v Českých Budějovicích, Pedagogická fakulta, Katedra biologie
}

Redakci zasláno 20. 8. 2019 / upravená verze obdržena 30.1. 2020 /

k uveřejnění přijato 23. 3. 2020

\begin{abstract}
Abstrakt: Přehledová studie zpracovává aktuální domácí a zahraniční přístupy k využívání videa v učitelském vzdělávání. Poukazuje na kontinuitu vývoje, kdy se videozáznamy původně pořizované pro výzkumné účely v přibývající míře používají v přípravném a dalším vzdělávání učitelů. Přehledová studie je rozvržena do čtyř částí. V první části je pojednán kontext učitelského vzdělávání, v němž se videa používají, a je zde představeno devět vybraných přístupů, které jsou v odborné literatuře zdokumentovány. Ve druhé části jsou zodpovídány čtyři otázky, které si přehledová studie klade: (1) Jak je daný přístup začleněn do rámcové koncepce učitelského vzdělávání / podpory profesního rozvoje? (2) Jaké cíle/účely stojí v základu daného prrístupu? (3) Jaké komponenty jsou součástí celku a jakou plní funkci? (4) Jaké konkrétní aktivity (uživatelů, popř. tutorů či tvůrců) jsou s videem v rámci přístupu realizovány a co se jimi má rozvíjet? Ve třetí části přehledové studie jsou diskutovány výzvy, které se v dané oblasti objevují, jakkoliv ještě mnohdy nejsou reflektovány v související odborné literatuře. Jedná se o možnosti využití virtuální reality a $360^{\circ}$ videí a o možnostech simulované a inscenované výuky jako alternativě videozáznamů - to vše $\mathrm{v}$ etických souvislostech využívání videa v učitelském vzdělávání. Čtvrtá část přehledové studie je výhledem, který se pokouší odpovědět na otázku, zda lze formulovat určitá měkká doporučení (guidelines), která by mohla vést vývoj v této oblasti.
\end{abstract}

Klíčová slova: video v učitelském vzdělávání, přípravné vzdělávání učitelů, profesní rozvoj, výuka

Video v učitelském vzdělávání není rozhodně žádnou novinkou. Má za sebou relativně dlouhou historii a bez nadsázky lze říct, že se stalo všudypřítomným fenoménem (Janík, Dalehefte, \& Zehetmeier et al., 2019). Vývoj využívání

1 Studie byla zpracována v rámci řešení projektu TA ČR Hyperspace pro formativní hodnocení a badatelsky orientovanou výuku v prírodovědných predmětech a matematice (TL02000368). Autoři děkují za poskytnutou podporu. Dále děkují anonymním recenzentům rukopisu, jejichž připomínky vedly k jeho zlepšení. 
videa v přípravě učitelů mapuje Sherinová (2004), která identifikuje vývojové milníky na dlouhé cestě od filmových záznamů v 60. letech 20 . století až k tvorbě hypermediálních programů počínající v poslední dekádě 20 . století. Způsoby využívání videa odrážely nejen paradigmatické změny v pedeutologii, ale nevyhnutelně i technologický rozvoj, který zejména v poslední době významně přispěl ke zvýšení dostupnosti videa a jeho využitelnosti v profesní přípravě. Po přelomu tisíciletí dochází celosvětově $\mathrm{k}$ významnému nárůstu v míre využívání videa v přípravném i dalším vzdělávání učitelů, a to napříč předměty a stupni vzdělávání, jak to dokumentují ve své přehledové studii např. Gaudin a Chaliès (2015), kteří analyzovali 255 odborných studií publikovaných na toto téma v letech 2003 až 2013.

Video v profesní přípravě učitelů nabývá různorodých forem, které se opírají o různé teoretické rámce - Gaudin a Chaliès (2015) uvádějí bez nároku na úplnost více než 30 rámců, ze kterých příslušné videopřístupy vycházejí. Podíváme-li se na způsoby využívání videa ve vzdělávání učitelů v posledních dvou desetiletích optikou výzkumu, lze identifikovat čtyři hlavní oblasti, které jsou v centru pozornosti výzkumníků (Gaudin \& Chaliès, 2015, s. 45): povaha aktivity učitele při sledování videa, cíle sledování videa, typy využívaných videí a vliv sledování videa na přípravné vzdělávání a profesní rozvoj učitelů. Posledně jmenovaná oblast zahrnuje i doporučení pro vzdělávací praxi a návrhy, jak překonávat limitace videa jako prostředku ve vzdělávání učitelů, což nás bude mj. zajímat i v tomto textu.

Využívání videa ve vzdělávání učitelů má úctyhodnou tradici i v České republice (Janík et al., 2011, s. 41-43), připomeňme např́klad aktivity audiovizuálních center na univerzitách v Brně či Hradci Králové, které se vztahovaly k profesní př́ípravě učitelů nebo lékařủ. Česká republika nezůstala pozadu za světovým vývojem ani v posledních desetiletích. Tento text je výrazem kontinuálního zájmu o problematiku videa v učitelském vzdělávání, navazuje na dřívější práce vzniklé na Pedagogické fakultě Masarykovy univerzity (např. Janík et al., 2009) a na dalších institucích v ČR - např. na Univerzitě v Pardubicích, na Pedagogické fakultě Univerzity Karlovy v Praze apod. (srov. Janík et al., 2011).

Uvažujeme-li o videu v učitelském vzdělávání v souvislosti s diskusí o učitelské profesionalizaci, do centra našich úvah se dostane video zejména jako prostředek rozvoje profesního vidění (professional vision). Tento termín poprvé použil Goodwin (1994) pro označení jednoho ze znaků profesí. Profesním 
viděním rozumí soubor diskursivních praktik používaných členy profese ke strukturování událostí v poli, které je předmětem jejich profesního pozorování (Goodwin, 1994, s. 606). Do českého pedagogického diskursu termín profesní vidění uvedli Minaříková a Janík (2012), kteří jej chápou jako jednu z dimenzí profesionality učitele zahrnující profesní vidění, profesní vědění a profesní jednání. Jedná se o neoddělitelné složky, profesní vidění a profesní vědění se projevuje v profesním jednání.

Profesní vidění podle Sherinové (2007, s. 384) zahrnuje dvě komponenty všímání si (noticing) / výběrové zaměření pozornosti (selective attention) a uvažování založené na vědění (knowledge-based reasoning). V souladu $\mathrm{s}$ tímto pojetím profesního vidění (u) učitelů je i definice Minaříkové a Janíka (2012, s. 196). Výběrovým zaměřením pozornosti rozumí identifikování relevantních znaků určité situace, které jsou důležité pro dosažení daného cíle - at' už se jedná o cíl jakéhokoliv druhu a jakékoliv úrovně. Uvažování založené na vědění zahrnuje dle autorů několik dílčích procesů - reprezentování, interpretování, vysvětlování, predikování, hodnocení výukových situací a navrhování alternativ a alterací.

Tuto teoretickou pozici autorů sdílíme, stejně jako jejich pojetí vztahu profesního vidění a reflexe (Minaříková \& Janík, 2012, s. 197-199). Zohlednímeli dva možné náhledy učitele na výuku (učitel jako aktér výuky nebo jako její pozorovatel), můžeme vztah profesního vidění a reflexe uchopit pomocí konceptu profesního vidění učitele jemněji diferenciovat proces reflexe a přispět k jeho operacionalizaci pojmenováním (rozlišením) subprocesủ. Za základní lze přitom považovat tři: reprezentování (popisování), analyzování a navrhování alternativ postupu. Z této teoretické pozice přistupujeme dále $\mathrm{v}$ tomto přehledovém textu $\mathrm{k}$ výběru videoprostředí, která následně podrobněji představujeme. Jejich výběr je tedy veden účelem a tento účel vychází z teoretického vymezení konstruktu profesního vidění.

Cílem tohoto textu je analyzovat, jak jsou vybrané zahraniční a domácí přístupy k využívání videa koncipovány a zaváděny do praxe, jaké výzvy se zde otevírají a jak na ně lze reagovat.

\section{Analyzované přístupy: otázky a odpovědi}

V následující části (formou tabulky 1) uvádíme stručné charakteristiky deseti domácích i zahraničních videoprostředí vybraných pro analýzu. Vybrány 
byly na základě aktualizace našich předchozích rešerší (srov. Janík et al., 2011) se zohledněním informací o nejnovějším vývoji v této oblasti v zahraničí (např. Gaudin \& Chaliès, 2015; Janík, Dalehefte, \& Zehetmeier et al., 2019). Vybraná videoprostředí prezentují různorodost cílů a účelů svého vzniku, jedná se tedy o účelem vedený výběr.

\section{Tabulka 1}

\section{Devět analyzovaných prístupů}

\begin{tabular}{|c|c|}
\hline Název př́ístupu & Charakteristika př́stupu \\
\hline $\begin{array}{l}\text { Lesson Lab (USA/ } \\
\text { Švýcarsko) } \\
\text { http://www.lessonlab. } \\
\text { com } \\
\text { (v současnosti již } \\
\text { nedostupné) }\end{array}$ & $\begin{array}{l}\text { Hodiny pořízené v rámci mezinárodně srovnávacích } \\
\text { videostudií TIMSS } 1999 \text { byly využity s cílem podpořit možnosti } \\
\text { pozorování výuky a diskutování o ní. K diskusím byli přizváváni } \\
\text { studenti učitelství i pedagogické psychologie a v první řadě } \\
\text { samotní učitelé. V současné době již platforma Lesson Lab } \\
\text { nefunguje, nicméně existují její funkční verze (např. Portál } \\
\text { unterrichtsvideo.ch). }\end{array}$ \\
\hline $\begin{array}{l}\text { LUV: Lernen aus } \\
\text { Unterrichtsvideos } \\
\text { (Německo) }\end{array}$ & $\begin{array}{l}\text { V př́́padě LUV (něm. Lernen aus Unterrischtsvideos - } \\
\text { Učení se z výukových videí) primárně nešlo o tvorbu } \\
\text { videoprostředí pro učitelské vzdělávání. Cílem bylo vyvinout } \\
\text { diagnostický nástroj na podchycování profesního vidění } \\
\text { (něm. Unterrichtswahrnehmung). Nástroj byl pro výzkumné účely } \\
\text { vytvořen na Institutu pro didaktiku př́rodních věd a matematiky } \\
\text { v Kielu a dále byl rozvinut na Technické univerzitě v Mnichově. } \\
\text { Na webu není dostupný, nicméně v komunitě zabývající se touto } \\
\text { problematikou je často využíván. }\end{array}$ \\
\hline $\begin{array}{l}\text { VIU Early Science } \\
\text { (Německo) } \\
\text { www.uni-muenster.de/ } \\
\text { koviu }\end{array}$ & $\begin{array}{l}\text { Toto videoprostředí lze asi nejvýstižněji charakterizovat } \\
\text { jako databanku videoklipů z výuky různých výukových } \\
\text { témat v různých vyučovacích předmětech na různých } \\
\text { typech a stupních škol v Německu. Videoklipy jsou opatřeny } \\
\text { podrobnými kontextuálními informacemi a také otázkami a úkoly } \\
\text { pro (budoucí) učitele, které je vedou při jejich analýze. }\end{array}$ \\
\hline $\begin{array}{l}\text { Virtuální hospitace } \\
\text { (Česká republika) } \\
\text { Švecová (2011) } \\
\text { https://digifolio.rvp.cz/ } \\
\text { view/view.php?id=1645 } \\
\text { https://audiovideo.rvp. } \\
\text { cz/kategorie/H }\end{array}$ & $\begin{array}{l}\text { Virtuální hospitace zastřešují sérii aktivit někdejšího } \\
\text { Výzkumného ústavu pedagogického v Praze; zejména projektu } \\
\text { KURIKULUM G, který podporoval učitele v praxi zveřejňováním } \\
\text { videozáznamů hodin a organizováním navazujících on-line } \\
\text { i off-line diskusí s učiteli, kteří zaznamenanou výuku vedli, } \\
\text { s přizvanými oborovými didaktiky a s dalšími zájemci. Video } \\
\text { bylo chápáno nejen jako inspirace pro vlastní výuku, ale } \\
\text { také jako východisko pro sdílení zkušeností v rámci profesní } \\
\text { komunity učitelů. I s odstupem téměř deseti let jsou videodata } \\
\text { (videozáznamy hodin) z celého spektra školních oborů i záznamy } \\
\text { realizovaných diskusí stále k dispozici. Vedle videozáznamů } \\
\text { celých hodin jsou postupně doplňovány i kratší videozáznamy } \\
\text { zaostřené na konkrétní témata. }\end{array}$ \\
\hline
\end{tabular}


DiViWeb (Česká

republika)

Slavík et al. (2017)

http://didacticaviva.ped. muni.cz/
DiViWeb je název pro elektronické prostředí vyvinuté na Pedagogické fakultě Masarykovy univerzity v Brně v rámci dlouhodobé snahy rozvíjet didaktickou poznatkovou základnu. Jsou publikovány didaktické př́ípadové studie, jež staví na analýzách autentických videozáznamů výuky různých školních předmětů na různých stupních a typech škol. Navazujícím krokem je poté hledání transdidaktického zobecnění, tj. hledání obecnějších aspektů (ne)kvality výuky, tzv. didaktické excelence či didaktických formalismů. Video potom slouží pro ilustrování autentických projevů těchto abstraktních konstruktů např́klad v profesní přípravě učitelů.

Lesson Study (původně Japonsko) Lesson study, tedy výzkum výuky, je v japonském sociokulturním kontextu tradiční způsob podpory profesního rozvoje učitelů Fernandez (2002), Lewis, a učících se komunit. Nejedná se o jednotlivou aktivitu, ale Perry a Friendkin (2013), o sdílenou profesní kulturu, která má v Japonsku více než stoletou Murata (2011), Vondrová tradici a již se do dalších zemí světa rozšírila kolem přelomu (2019) tisíciletí. Japonská Lesson Study je v podstatě akční výzkum realizovaný v osmi fázích: definování problému, plánování vyučovací hodiny, realizace vyučovací hodiny, hodnocení a reflexe hodiny, revize plánu hodiny, realizace hodiny dle revidovaného plánu, opětovné hodnocení a reflexe, sdílení výsledků.

Z hlediska využití videa je důležitá fáze realizace vyučovací hodiny (tzv. research lesson), která má tyto charakteristiky: je pečlivě plánovaná většinou ve skupině spolupracujících učitelů, je pozorovaná jinými učiteli, je zacílená na určitý problém, je zaznamenávaná různými způsoby včetně videa, je učiteli diskutovaná.

Science Teachers Learning from Lesson Program profesního rozvoje STeLLA propojuje dva přístupy k profesnímu učení učitelů přírodovědných předmětů, a to zaměření na efektivní strategie výuky a profesní učení založené na analýze videa. Program, jehož cílem bylo transformovat učení učitelů i žáků, vznikl v Kalifornii v úzkém sepětí s výzkumem, posléze byl implementován i v dalších státech USA. Implementace programu STeLLA v př́ípravném i v dalším vzdělávání učitelů je výzkumně ověřována. learning-from-lessonanalysis

Problem solving cycle (USA) Koellner et al. (2007)
PSC představuje model profesního rozvoje učitelů matematiky, ve kterém se učitelé mají naučit podporovat matematické uvažování svých studentů. Model je tvořen sérií tř́ na sebe navazujících workshopů, z nichž každý má přesně definovaný cíl, klíčové aktivity a cílové znalosti, které má rozvíjet (zaměření na znalost obsahu i didaktickou znalost obsahu), a je do značné míry založen na práci s videem - analýza zaznamenaných vyučovacích hodin představuje klíčovou aktivitu druhého a třetího workshopu. 
Videokluby (USA / Česká Ve videoklubech se pravidelně setkávají učitelé z praxe; kromě republika) toho je v roli facilitátora prrítomen také oborový didaktik

Sherin (2007), Janík et al. z fakulty připravující učitele. Podnětem pro diskuse je zhlédnutí (2016) videosekvence z výuky. V prvním kroku se jedná o „cizí“ videa (např z projektů Virtuální hospitace, Videostudie TIMSS) později o videa z vlastní výuky účastníků. Z úvodních setkání se generují témata, která jsou pro učitele zajímavá a která se „řeši“ na dalších setkáních. Cílem je to, aby diskutovaná témata byla iniciována samotnými učiteli a byla pro ně relevantní. Výstupem práce ve videoklubech jsou mj. plány či scénáře aktivit nebo úloh pro vyučovací hodiny.

Dále uvádíme analýzu vybraných videopřístupů. Otázky pro analýzu jsou v souladu s orientací výzkumu na využívání videa ve vzdělávání učitelů (Gaudin \& Chaliès, 2015).

1. Jak je daný př́stup začleněn do rámcové koncepce učitelského vzdělávání / podpory profesního rozvoje (kdo je jeho tvůrcem a kdo je adresátem)?

2. Jaké cíle/účely stojí v základu daného přístupu?

3. Jaké komponenty jsou součástí celku a jakou plní funkci?

4. Jaké konkrétní aktivity (uživatelů, popř. tutorů či tvůrců) jsou s videem v rámci videoprostředí realizovány a co se jimi má rozvíjet?

\subsection{Začlení př́stupů do rámcové koncepce učitelského vzdělávání / podpory profesního rozvoje}

Přístupy analyzované $\mathrm{v}$ tomto textu jsou využívány $\mathrm{v}$ přípravném i dalším vzdělávání učitelů. Důvody vzniku některých z nich však byly původně jiné. Např́iklad $\mathrm{v}$ př́padě Lesson Lab videa nebyla primárně určena pro profesní rozvoj učitelů, nýbrž byla pořízena v rámci videostudie TIMSS 1999 a následně využita pro rozšiřrení možností pozorování výuky a diskuse o ní v př́ípravném vzdělávání učitelů. Podobně LUV bylo prostředí vytvořené pro výzkumné účely, konkrétně pro diagnostiku profesního vidění. Aktivity zastřešené názvem Virtuální hospitace na využití v učitelském vzdělávání také primárně necílily, nicméně místy se jako takové používají. Portál rvp.cz, na němž jsou videozáznamy a k nim příslušející data aktuálně umístěny, nenabízí žádné specifické analytické nástroje pro užití v profesní přípravě učitelů. Záměrem je ilustrovat současnou výuku a vytvořit př́ležitosti pro sdílení zkušeností z výuky, diskuse o způsobech realizace apod. Heslo, pod nímž 
nechávali učitelé participující v projektu do své výuky nahlédnout, znělo: "Jak se u nás učí“.

Další videoprrístupy byly adresně vytvořeny pro potřeby vzdělávání učitelů. Video v nich představuje centrální komponentu, na kterou jsou navázány další činnosti. V tomto ohledu se odlišuje japonská Lesson Study, jak bude uvedeno níže. Např. VIU je sbírkou videozáznamů z výuky primární př́rodovědy a dalších předmětů, které jsou určeny k pozorování a analýze. Obsahuje videoklipy rozčleněné do vícera tematických oblastí - vzdělavatelé učitelů je mohou dle vlastního uvážení nasazovat do své výuky na učitelských fakultách. Inovativnost přístupu rozvíjeného s oporou o DiViWeb spočívá v tom, že vytvářené didaktické kazuistiky jsou dílem malých autorských týmů (2-3 kolegů), v nichž se setkává teoretická expertnost akademiků / vzdělavatelů učitelů s praktickou expertností praktikujících učitelů. Jádrovým pojmem je zde profesní společenství. Pro učitelské vzdělávání má potenciál v tom, že v diskusích nad videozáznamem výuky generuje specifický typ vědění a s ním spojený způsob uvažování o kvalitě výuky, které se v učitelské přípravě ukazují jako cenné. Tím může napomoci přinést změnu ve způsobu chápání kvality výuky jako jednoho z klíčových konceptů učitelské př́ípravy i učitelské profese.

Pro další skupinu přístupů je typické, že video je v nich součástí déletrvajících běhů či kursu v přípravném, a zejména v dalším vzdělávání učitelů. Analýza videa představuje jeden ze dvou pilírů programu profesního rozvoje STeLLA, druhým pak je prohlubování obsahu a didaktické znalosti obsahu - učitelé se učí analyzovat video ze dvou hledisek: z hlediska žákovského uvažování a $\mathrm{z}$ hlediska prŕběhu př́rodovědného obsahu ${ }^{2}$. Program probíhá ve třech fázích, ve všech fázích jsou adresáty videa učitelé (Roth et al., 2015). Stejně tak i v PSC je video základem uvedeného modelu, který staví na analýzách výuky matematického problému (Koellner et al., 2007). Profesní (video)kluby představují formu dalšího vzdělávání učitelů, která spočívá v utvoření profesního společenství, v němž učitelé za podpory zpravidla oborových didaktiků z fakult připravujících učitele usilují o zlepšování své výuky na základě její reflexe a sdílení znalostí a zkušeností (srov. Janík et al., 2016).

Na rozdíl od předchozích videopř́stupů, kde má video centrální roli, se v japonské Lesson Study uplatňuje jako dílčí nástroj během jedné fáze procesu,

2 Hovoří se o souvislém příběhu obsahu, nebot' mezi úvodní otázkou, hlavní myšlenkou a následnou diskusí, aktivitami a zakončením hodiny byly viditelné vazby. 
tzv. research lesson. Tato výzkumná / badatelská vyučovací hodina je otevřená pro pozorovatele $\mathrm{z}$ řad učitelů školy, města, regionu či celého Japonska. Primární je observace v reálném čase, pozorovatelé si pořizují terénní zápisky o učení studentů nebo pracují s observačními protokoly. Vyučovací hodina je dále zaznamenávána různými způsoby, video představuje jeden z nich. Běžně se využívá více kamer. Video je zacíleno na vybraný aspekt výuky, který se participující učitelé rozhodnou na začátku celého procesu zkoumat. Ukazuje se, že implementace Lesson Study v různých zemích má odlišnou podobu s ohledem na specifika dané země a proměnlivá tak může být i role videa. Např́íklad při realizaci výzkumu výuky matematiky v českém prostředí (Vondrová, 2019) se ukázalo jako vhodnější nahradit observace v reálném čase právě videem. Důvodem byly jednak organizační záležitosti, jednak neexistující kultura vzájemných hospitací mezi českými učiteli. Video se tak stalo základem pro následné analytické procesy a (sebe)reflexi.

Uvažujeme-li o adresátech uvedených př́stupů, byli jimi primárně učitelé z praxe - jsou tady doménou dalšího vzdělávání učitelů, resp. podpory jejich profesního rozvoje. Některé z nich, resp. jejich prvky, si kromě toho našly cestu i do přípravného vzdělávání učitelů nebo byly pro jeho potřeby adaptovány (napřs STeLLA). Co se týká oborového zaměření, s výukou př́rodovědných předmětů jsou primárně spojeny VIU a STeLLA, PSC vznikl pro potřeby učitelů matematiky. Ostatní př́stupy jsou oborově otevřené.

\subsection{Cíle a účely př́stupů}

Na obecné rovině můžeme rozlišovat př́istupy podle cílů, které sledují, na ukázkové, analytické a návrhové. Podíváme-li se touto optikou na námi analyzované př́stupy, můžeme je rozdělit do několika skupin podle účelu, který stojí v základu daného př́ístupu. Některé přístupy sledují paralelně či sekvenčně více cílů různé priority. Pro potřeby analýzy pracujeme s cíli explicitně vyjádřenými tvůrci daného videoprostředí, možné modifikace k jiným účelům neuvažujeme, i když vyloučeny nejsou.

Lesson Lab a Virtuální hospitace jsou primárně ukázková videoprostředí. Videoukázky v Lesson Lab měly reprezentovat jednotlivé kultury vyučování a učení a ilustrovat, jaké procesy ve školních tř́dách (v jednotlivých kulturách) probíhají. Pokud jde o Virtuální hospitace, hlavním cílem projektu bylo prezentování „současné“ výuky na gymnáziích (a později základních školách) formou "příkladů inspirativní praxe“ a vytvoření př́ležitosti pro společné 
nestrukturované přemýšlení ve společenství zahrnujícím učitele-aktéra, didaktika-experta a pozorovatele-hosty (formou on-line i off-line elektronického chatu). Tyto cíle byly naplněny samotným zveřejněním videozáznamů a souvisejících informací a dat.

Skupina primárně analytických videoprostředí zahrnuje DiViWeb, Lesson Study, PSC a Videokluby. V přístupu rozvíjeném kolem DiViWebu je video využito jako tzv. mikroskop sociálních věd; umožňuje analýzu komplexních procesů vyučování a učení (v provázanosti) na mikroúrovni výukové situace. Výsledná kazuistika je chápána jako ilustrace oborovědidaktického (didaktického, kurikulárního) konceptu a jeho promítnutí v autentické výuce. A právě k ilustraci a zpětné prezentaci výsledného abstraktního konstruktu slouží videozáznam zpravidla lépe než verbální popis. Jednou z charakteristik Lesson Study je zacílení na učení žáků. Cílem pozorovatelů během výzkumné vyučovací hodiny (research lesson) je zaznamenat co nejvíce informací, důkazů o učení žáků, $v$ japonském kontextu zejména prostřednictvím pozorování i audio či videozáznamu. Video je tak jedním z dalších informačních zdrojů, který zachycuje výuku v její komplexnosti a umožňuje následnou analýzu. Alternativně může video zcela nahradit př́mé pozorování vyučovací hodiny. Zacílení analýzy je dáno výzkumným problémem stanoveným na začátku Lesson Study a podpořeno využitím observačních protokolů. Podobně i PSC je model stavějící na analytickém př́stupu. Zaznamenaná výuka matematického problému je analyzována jednak $\mathrm{z}$ hlediska role učitele $\mathrm{v}$ této výuce a také z hlediska matematického uvažování žáků. Pozornost učitelů je směrována $\mathrm{k}$ příslušnému hledisku prostřednictvím návodných otázek. Cílem videoklubů je rozvíjet profesní vidění pro určitou složku profesní vybavenosti učitele (např pro vědomý rozvoj komunikační kompetence ve výuce cizích jazyků, pro podporu učebních procesů žáků v matematice, pro konstruktivní práci s chybou v př́rodovědných předmětech). Pracuje s úrovní popisnou, analytickou a návrhovou. Tím se generuje profesní jazyk a didaktická (a jiná) terminologie. V sekvenci videoklubů je analyzování spojeno s plánováním výuky.

Propojení ukázkových a analytických účelů stojí v základu videoprostředí VIU a STeLLA. Ve VIU se videa vztahují k různým aspektům výuky (ř́zení třídy, podpora učení atd.) a k různému učivu z primární přírodovědy (či dalších předmětů), jako opora jsou k dispozici podněty pro reflexi videí - ve vztahu k různým formám podpory učení (např. uchopování žákovských představ, 
podněcování diskuse o představách a konceptech, vyzdvihování významných aspektů představ, shrnování diskusí vztahujících se k představám apod.). Otázky k analýze videí jsou např. typu: Proč učitel volí právě ty a ty výroky/pojmy? Jaké podněty dětem nabízí k porozumění? Proč učitel vyzdvihuje právě to či ono? Jak má učitel žáky připravit na to, aby porozuměli tomu či onomu? Program STeLLA je koncipován do několika fází. Cíle videopřístupu se $\mathrm{v}$ jednotlivých fázích programu liší. $\mathrm{V}$ úvodní fázi jsou primárně ukázkové, hlavním cílem je modelování strategií STeLLA. V dalších fázích převažují cíle analytické, učitelé provádějí kolaborativní analýzu videa, a to z pohledu již zmíněných hledisek (žákovské uvažování, příběh přírodovědného obsahu). Analytické procesy jsou facilitovány prostřednictvím specifických analytických nástrojů, které zahrnují průvodce analýzou (Analysis Guide), protokol (STeLLA Lesson Analysis Protocol) a tabulku pro hodnocení pokroku žáků a identifikaci problémových oblastí (STeLLA Assessment Features Analysis Chart).

Od ostatních videopřístupů se odlišuje LUV, který byl navržen primárně pro potřeby výzkumu. Nicméně jakožto diagnostický nástroj naplňuje také svůj vedlejší (intervenční) efekt, jímž je rozvíjení schopnosti vnímání (analyzování) výuky. Pří výzkumu se sleduje, zda respondenti produkují popisné, analytické či návrhové výroky k pozorované výuce.

Jak vyplývá z výše uvedeného, při sledování analytických cílů je proces analýzy podpořen různými strategiemi - pozornost učitelů je cíleně zaměřována na předem definované aspekty výuky, a to prostřednictvím návodných otázek, úkolů, identifikací zkoumaného problému či různých specifických nástrojů. Nejvyšší míra rrízenosti analytických procesů je patrná v programu STeLLA, kde koncept dvojích "brýlí" stojí v základu daného videoprrístupu, což je reflektováno v konstrukci odpovídajících analytických nástrojů (průvodce analýzou, protokol, tabulka pro hodnocení pokroku žáků a identifikaci problémových oblastí).

\subsection{Komponenty př́stupů a jejich funkce}

Video zprostředkovává pozorovatelům komplexní realitu školní třídy. Většina př́stupů prezentuje skutečnou výuku, kdy se učitel i žáci chovají autenticky. Př́stupy STeLLA a Lesson Study se odlišují tím, že autenticky se chovají pouze žáci, učitel jedná podle předem připraveného plánu, který je výsledkem diskuse v odborné komunitě. Žádný z přístupů nevyužívá simulovanou či inscenovanou výuku. 
Ve vzdělávání učitelů je využíváno video vlastní i cizí, a to v závislosti na cílech jednotlivých př́istupů. Všechny analyzované přístupy staví na potenciálu videa cizího. Některé přístupy kombinují oba typy videí, a to v návaznosti na různou fázi procesu (např. STeLLA, Videokluby) nebo v závislosti na perspektivě jednotlivých účastníků (jeden učitel sdílí s kolegy vlastní video jako např v programu PSC či LS). Ve všech př́ípadech je video doplněno dalšími komponentami, které plní specifické funkce a zvyšují potenciál videa.

Cizí video je využíváno v Lesson Lab - jsou zde obsaženy videozáznamy výuky (data z TIMSS 1999) a základní funkcionality pro práci s videem, tj. markery pro propojení videodat s doslovným přepisem verbálních interakcí. Cizí videa jsou využívána také ve VIU - řádově jde o desítky videoklipů (obsahující anotace každé scény), transkripty hodin, průběhové protokoly, pracovní listy a materiály z výuky (záznamy na tabuli), úkol pro analýzu, kontextové informace. V LUV jsou používána také cizí videa a dále soubory škál $k$ vybraným parametrům kvality výuky, dialogová okna pro psaní vlastních komentářů/ reflexí k pozorované výuce apod. Pokud jde o Virtuální hospitace, také ty typicky využívají videozáznamy cizí výuky. Typický soubor informací z hospitované hodiny zahrnuje 45 minutový záznam výuky realizované v některém ročníku gymnázia, úvodní slovo učitele k záměru a kontextu hodiny, závěrečné slovo učitele s reflexí realizované výuky, post-hoc analýzu didaktika-experta, záznam on-line diskuse, jež byla organizována ke každé „premiéře“, a záznam následné (neukončené) off-line diskuse. Výhodou tohoto přístupu je mnohost nabízených pohledů od pohledu aktéra přes pohled odborníka až po pohledy laiků (např. rodičů). Právě možnost nahlédnout na perspektivy (a diskursy) různých pozorovatelů může být vnímána jako klíčový přínos k reflektivní přípravě (budoucích) učitelů.

V dalších přístupech jsou kombinována video vlastní $i$ cizí. V DiViWebu jsou typicky diskutovány jak videozáznamy vlastní, tak i cizí výuky. To je dáno tím, že členem autorského kolektivu pracujícího na didaktické kazuistice může (ale nemusí) být i učitel, z jehož výuky je vybrána výuková situace zachycená na videozáznamu, kolem které je kazuistika utvářena. Zpracovávána potom jsou nejen verbální data (transkripty interakcí, př́pravy na výuku), ale i data obrazová; např. fotosnímky (zápisy na tabuli), artefakty (pracovní listy žáků ukazující způsob řešení problémů).

V rámci Lesson Study se s videem pracuje ve fázi hodnocení a reflexe vyučovací hodiny. Jedná se o video vlastní z pohledu učitele, který hodinu 
naplánovanou v komunitě vyučuje a nabízí k diskusi mezi ostatní účastníky, pro které představuje nahrávka video cizí. Učitelé a případní další účastníci Lesson Study pracují dále se strukturovanými či nestrukturovanými observačními protokoly, plánem vyučovací hodiny, produkty činnosti žáků, audiozáznamy atd. Hlavní funkcí všech komponent je komplexně zdokumentovat danou vyučovací hodinu a získat co největší množství informací (důkazů) různého typu o učení žáků. $V$ programu STeLLA představuje práce $s$ videem podstatnou část programu, věnována jí je přibližně polovina časové dotace. V úvodní fázi programu je akcentována ukázková funkce videa a je využíváno nejprve video cizí, $v$ dalších fázích převažuje funkce analytická a pracuje se s videem vlastním i cizím. Učitelé také pracují s plány vyučovacích hodin, nejprve s modelovými, dále s plány kolaborativně vytvořenými. Pro analýzu videa jsou využívány různé analytické nástroje (viz část 2.2), které ji mají zacílit na předem vybrané aspekty vyučovací hodiny (žákovské uvažování, př́běh př́rodovědného obsahu). $\mathrm{V}$ rámci PSC se $\mathrm{s}$ videem pracuje ve druhém a třetím workshopu. Jedná se o video každého ze zúčastněných učitelů, tedy video vlastní i cizí, v závislosti na pohledu jednotlivých účastníků. Tím se tento videopřístup liší od Lesson Study, kde se na videu objevuje pouze jeden učitel, prŕpadně více učitelů podle toho, kolikrát se celý cyklus opakuje. Učitelé v kontextu PSC také analyzují další zdroje informací, zde konkrétně produkty činnosti žáků (důkazy o řešení matematického problému). $V$ př́ipadě videoklubů se nejdříve pozoruje cizí video, pak vlastní video, vznikají plány/př́pravy vlastních hodin, ty jsou odučeny a nahrány na video, a to je opět analyzováno. Pro podporu práce ve videoklubech mohou být vytvořeny úkoly či pracovní listy, a to s cílem podporovat učební proces u účastníků videoklubů.

\subsection{Konkrétní aktivity s videem v rámci videoprostředí a jejich cíle}

Pokud jde o Lesson Lab, webové nástroje pro interakci uživatelů byly v době jeho vzniku z dnešního pohledu v plenkách. Využívány byly systémy otázek a odpovědí a nástroje pro popis jednotlivých částí videozáznamů. Videomarkery umožňovaly připisovat úkoly k jednotlivým úsekům/aspektům zaznamenaných hodin. V případě VIU jsou učící se vyzýváni ke sledování klipů, jsou jim dávány podněty $\mathrm{k}$ analýze videí ( $\mathrm{z}$ hlediska obsahu i z hlediska jeho zpracování). Má potenciál rozvíjet učitelovy představy o možnostech práce ve třídě s konkrétním učivem a má potenciál vybavovat ho didaktickými znalostmi obsahu a znalostmi metodických postupů. Autoři LUV vytvořili klipy 
a soubory škál a k nim dialogová okna, jeho uživatelé (respondenti) v LUV pracují (posuzují kvalitu, komentují výuku), a tím o sobě generují výzkumná data, přičemž současně rozvíjí svoji analytickou kompetenci.

V př́ípadě Virtuálních hospitací nebyly realizovány jiné aktivity než organizované elektronické diskuse. Tyto diskuse měly dvojí podobu. Jednak byla ke každému videozáznamu ve vyhlášeném termínu realizována „on-line“ diskuse se zvanými hosty včetně participujícího učitele, s možností adresovat v diskusních vláknech nejrůznější aspekty zaznamenané výuky od konkrétních uplatněných didaktických postupů a strategií přes obecnější témata jako klima třídy či způsoby práce s učebnicí až po obecné otázky koncepce daných školních předmětů $v$ rámci státního kurikula. Kromě toho potom byla ke každému videozáznamu otevřena možnost diskutovat „off-line“ v dalších týdnech a měsících a dále tak rozvíjet různé pohledy na zachycenou reálnou výuku. Další následné využití videí nejrůznějšími uživateli internetu nemá limitů, existují informace o využívání těchto videí mimo jiné na semináŕích profesního rozvoje učitelů či školních inspektorů.

V DiViWebu slouží video části hodiny (cca 3-12 minut) jako východisko pro analýzu výukové situace. $\mathrm{V}$ dialogu v profesním společenství (v autorském týmu, i v širším okruhu ad hoc konzultantů) identifikují tvůrci kazuistiky jádrové pojmy z hlediska tématu (svět žáků), obsahu (svět oboru) a nadoborových cílů (kompetence) - a vztahy mezi nimi. S oporou o tuto analýzu je konstruován myšlenkový experiment o možných změnách (alteracích) a jejich důsledcích pro kvalitu vyučování a učení v dané výukové situaci. Takový způsob uvažování je na jednu stranu cenný pro rozvoj př́slušné oborovědidaktické teorie, na druhou stranu dokáže napomoci kultivaci praktického uvažování o kvalitě (vlastní) výuky. Pomáhá tedy překlenout (at' už skutečnou, nebo domnělou) propast mezi didaktickou teorií a praxí.

Cílem aktivit účastníků výzkumné vyučovací hodiny (tzv. research lesson) v rámci Lesson study je analyzovat video jako zdroj informací o učení žáků z předem stanovené perspektivy. Analýzy videa a ostatních dat mají umožnit odpovědět na otázku, zda byla výuka efektivní.

Program STeLLA probíhá ve třech fázích, v první fázi si učitelé osvojují strategie STeLLA a analyzují cizí videa z pohledu těchto strategií. Ve druhé fázi učitelé využívají připravené plány hodin se strategiemi STeLLA a společně analyzují cizí i vlastní videa a učení studentů a revidují plány vyučovacích hodin. Ve třetí fázi pak analyzují videa a společně plánují vyučovací hodiny, 
které pak individuálně vyučují. V průběhu programu se postupně snižuje míra podpory - nejprve jsou poskytnuty modelové plány vyučovacích hodin, později učitelé plány společně vytvářejí a v závěru se očekává individuální práce. Aktivity směřují k rozvoji znalosti obsahu a didaktické znalosti obsahu (žákovské uvažování, př́iběh přírodovědného obsahu).

Cílem aktivit účastníků PSC je analyzovat video z hlediska role učitele a matematického myšlení žáků. Video slouží jako odrazový můstek pro zkoumání různých témat a diskusi o nich (např jak učitelé prezentovali úkol; jak ř́dili rozpravu ve tř́dě; jak různé matematické reprezentace, např. grafy, rovnice, tabulky, obrázky, podporují různé strategie řešení). Tyto aktivity směřují k rozvoji znalosti obsahu a didaktické znalosti obsahu.

Ve videoklubech účastníci video popisují, analyzují a dávají návrhy jiných možných postupů. Plánují také vlastní hodiny. Ve spojení analyzování a plánování je spatřrován důležitý princip videoklubů. Videokluby generují profesní jazyk - směřují k vyjednávání významů pozorovaného a podporují rozvoj profesionality učitelů.

Potud naše analýza stávajících přístupů $\mathrm{k}$ využívání videa v prrípravném a dalším vzdělávání učitelů. Ukázali jsme, že práce s videozáznamy výuky nabývá své konkrétní podoby v závislosti na tom, jak je začleněna do určité koncepce učitelského vzdělávání, resp. podpory profesního rozvoje. Práce s videozáznamy výuky sleduje široké spektrum cílů - od rozvíjení profesních dispozic učitelů k popisu přes analýzu výuky až k návrhům na její zlepšování, přičemž prvně zmíněné převažují. Video se v žádném programu učitelské př́pravy nenachází osamoceno, naopak je včleněno do souboru různých postupů a metodických opor či materiálů a je obohaceno o další materiály, jako jsou otázky pro reflexi, posuzovací škály apod. V průběhu času se objevily některé výzvy, na něž byly zaznamenány určité reakce. $V$ další části textu se zaměříme na některé $\mathrm{z}$ nich.

\section{Související výzvy a možná řešení}

\subsection{Virtuální realita a 360stupňová videa}

S rozvojem techniky se v oblasti využívání videa v profesní přípravě etabloval nový segment spojený s využitím virtuální reality, rozšířené reality a 360stupňových videí. Virtuální realita (z angl. virtual reality) umožňuje uživateli seznámit se s prostředím, které je virtuálně simulováno, a uživatel 
má často možnost s vybranými prvky v tomto prostředí interagovat. Hlavním účelem virtuální reality je navození iluze skutečného prostředí, takže je hojně využívaná například v medicíně nebo ve vojenství. Rozšířená realita ( $\mathrm{z}$ angl. augmented reality) se oproti virtuální realitě odlišuje tím, že skutečné obrazy prostředí jsou doplněné virtuálními uměle vytvořenými objekty (Billinghurst \& Dünster, 2012). To znamená, že reálný objekt je nasnímán např́klad fotoaparátem a je doplněn o digitální prvky (např popis daného objektu, jeho vlastnosti apod.). Rozšířená realita tak uživateli umožňuje interakci s digitálním obsahem pomocí fyzické manipulace s danými objekty. Výsledkem je efektivnější demonstrace prostorových vztahů mezi objekty a prostředím, stejně jako vztahů mezi skutečnými a virtuálními objekty (Billinghurst \& Dünster, 2012).

360 stupňové video (často označované pouze jako $360^{\circ}$ video) představuje konkrétní technologii, v níž jsou pomocí speciální kamery snímány obrazy všemi směry. $V$ praxi to vypadá tak, že několik kamer zabere obraz z jednoho výchozího bodu, kde je př́stroj umístěn (Sheikh et al., 2016), ale uživatel má plnou volbu nad tím, kterým směrem zaměří svou pozornost. Samozřejmě, že celkový pohled lze měnit pohybem zařízení (Conroy, 2017), ale v tomto př́padě je stále plynoucí děj a možnost zaměření se na dílčí prvky procesu bez nutnosti manipulace $s$ kamerou bezesporu velkou výhodou užití tohoto typu videí (Vosmeer \& Schouten, 2014). Rozdílem oproti virtuální realitě je fakt, že se pozorovatel nemůže po prostoru pohybovat, manipulovat s objekty či jinak zasahovat do děje.

Reyna (2018) označuje za inspiraci pro 360stupňová videa program QTVR (z angl. QuickTime Virtual Reality) vyvinutý společností Apple v 90. letech. $\mathrm{V}$ tomto programu došlo $\mathrm{k}$ seskupení několika obrázků dohromady, takže si uživatel mohl pohybovat s celkovým obrazem. Koncem devadesátých let prrišel na trh Flash, který se s rozvojem mobilů a tabletů stal klíčovou aplikací. Společnost YouTube v roce 2015 zahájila podporu 360stupňových videí. V současné době již existuje větší množství výrobců, kteří 360stupňové kamery prodávají, což má pozitivní vývoj i na trh s těmito př́stroji, protože došlo k redukci jejich zpočátku velmi vysoké pořizovací ceny. Největším propagátorem 360stupňových videí je nyní společnost Google. Na Youtube je dokonce speciální kanál, který obsahuje pouze videa tohoto typu, je možné nalézt i kanál označený jako 360 Videos for Education. 
Výzkum v oblasti 360stupňových videí a jejich používání v různých oblastech je stále ve svém počátku, avšak první studie poukazují na fakt, že jsou tato videa velmi podnětná pro pozorovatele a umožňují silnou identifikaci s prezentovaným dějem (např. Argyriou et al., 2016; Fonseca \& Kraus, 2016). Výzkumy se zaměřují zejména na způsob, jakým uživatelé tato videa přijímají, jak pracují s jejich obsahem (Sheikh et al., 2016) či jaké mají návyky v jejich sledování (Tang \& Fakourfar, 2017) - např́klad trasováním jejich pohybů v rámci 360stupňových videí. Elmezeny a Wimmer (2018) dodávají, že ačkoliv existují počáteční výzkumy zaměřené na 360stupňová videa, žádný z těchto výzkumů neporovnává efektivitu 360stupňových videí s jinými formáty videa. Jinými slovy, studie se nezaměřují na fakt, zda se uživatel naučí více, pokud sleduje 360stupňové video, či například klasické video. Další spíše teoretické studie se zaměřují na mapování možností používání těchto videí a překážek spojených s jejich zaváděním do praxe. Dále se pokusíme shrnout nejen překážky, ale i potenciál užití 360stupňových videí.

\section{Limity použití 360stupňových videí}

Kavanagh s kolektivem (2016) shrnuje faktory, které do jisté míry omezují intenzivnější rozšíření užití virtuální reality a 360stupňových videí ve vzdělávání. Autoři, shodně jako Haluck (2000), Johnson s kolektivem (1998) a Wiecha s kolektivem (2010), označují za obecné obtíže vyšší pořizovací cenu zařízení a také nezkušenost uživatelů s jejich obsluhou. Finanční náročnost je spojena i s dlouhodobou údržbou, zajištěním aktualizací (Haluck, 2000; Naone, 2007), nutností proškolení uživatelů (Le, Pedro, \& Park, 2014) či zajištěním odborné pomoci u vytváření vlastního obsahu. Při užití 360stupňových videí je finanční náročnost nižší a obsluha je snadnější, takže nejčastěji jsou diskutovány problémy praktického charakteru, např́íklad velikost pořízeného záznamu, umístění kamery či zvolení vhodného úhlu pohledu. Kavanagh s kolektivem (2016) preferují umístění kamery ve výšce dospělého člověka na monopodu nebo stativu, aby získaný záznam poskytl realistický pohled na celou třídu.

Kavanagh et al. (2016) upozorňuje na další obtíž, se kterou se setkali při užívání virtuální reality či 360stupňových videí. Jedná se o ztrátu pozornosti uživatele, jelikož podnětů, které na osobu sledující video působí, může být mnoho, tudíž není schopen vybrat ten zásadní, na který by se měl zaměřit (Gieser, Becker, \& Makedon, 2013). Často je tedy potřeba uživatelům ukázat, co mají na takto komplexním záznamu sledovat. Ačkoliv právě vizuální 
podněty z celého prostředí jsou považovány za jednu z hlavních výhod virtuální reality, stejně tak je možné je označit za hlavní distraktor pozornosti, jelikož okolí může snadno rušit hlavní děj, který je uživatelům prezentován. Při použití virtuální reality také není nijak zaručeno, že se uživatel soustředí na to, co má opravdu sledovat. Uživatelé také mohou mít problémy s orientací ve videu, která jim může působit i zdravotní nepř́íjemnosti - v angličtině se setkáme s termínem „motion sickness“ (Abdul Rahim et al., 2012). Z výše zmíněných důvodů se doporučuje pořizovat pouze 10 až 20minutové sekven$c e$, které poskytují vhodnou formu z hlediska redukování velikosti souboru a fyzické nepohody při sledování videa. Uživatelé také po tuto dobu snáze udrží pozornost.

V neposlední řadě je zde nutné zmínit problém spojený s obecným nařízením o ochraně osobních údajů, tzv. GDPR (General Data Protection Regulation), jelikož na rozdíl od kamery umístěné v zadní části školní třídy 360stupňové video zabírá vždy obličeje některých žáků, takže je nutné mít zcela detailní souhlasy od zákonných zástupců žáků či žáků samotných (srov. Sonnleitner, Prock, \& Dietl, 2018).

\section{Možné využití 360stupňových videí ve vzdělávání}

Jaký je potenciál těchto videí pro vzdělávání, zejména ve vztahu k př́ípravě budoucích učitelů nebo profesnímu rozvoji učitelů z praxe? V USA se používají takzvané virtuální prohlídky (Joly, 2016), které mají za úkol postupně seznámit studenty učitelství s prostředím školní třídy i celé školy. Právě 360stupňová videa zde poskytují zajímavou možnost, jelikož znázorňují komplexní pohled na daný prostor. Ve výuce přírodovědných předmětů se nabízí nahrávání terénních cvičení či exkurzí. Takové video může posloužit jako záznam dané aktivity, nebo naopak může být použito před samotnou exkurzí jako instruktážní video, v němž jsou účastníci seznámeni s lokalitou, druhy žijícími v dané oblasti apod. (Reyna, 2018).

Tato videa umožňují studentům - budoucím učitelům - porozumět situacím v dané třídě v širším kontextu (Roche \& Gal-Petitfaux, 2017), jelikož velké pole záběru zachycuje souhrnné interakce mezi účastníky vzdělávacího procesu a je možné si je opakovaně přehrávat, a přitom zaměřit pozornost na různé aspekty (Pea et al., 2014). V přípravě budoucích učitelů lze 360stupňová videa využít také pro zlepšení prezentačních schopností a komunikačních dovedností, protože lze sledovat, jakým způsobem vedla daná 
osoba svůj výklad či prezentaci a jaké byly reakce publika. Yamashita a Taira (2016) podporují užití těchto videí v kombinaci s hodnoticím archem, který byl vyplňován týden po výstupu. Prezentující student měl poté možnost si několikrát přehrát video a podívat se na svůj výkon doslova z několika různých úhlů (Yamashita \& Taira, 2016).

360stupňová videa mohou poskytovat zajímavou zpětnou vazbu pro učitele nebo tvůrce vzdělávací politiky, jelikož lze s jejich pomocí hodnotit práci žáků např́klad při laboratorních pracích a sledovat, jak se vyrovnali se zadaným úkolem, popř́ípadě zda jsou schopni spolupracovat. Následně učitel reflektuje zjištěné závěry ve vztahu k chování žáků a může modifikovat danou aktivitu pro přiští užití. $V$ tomto případě je ale nutný souhlas všech žáků s nahráváním. Na stejném principu je založeno užití těchto videí pro výzkumné účely, zejména ve smyslu pozorování školní výuky, opět s důrazem na interakce mezi žáky či žáky a učitelem. Vhodnost užití se nabízí například při sledování skupinové práce, kdy 360stupňové video představuje neinvazivní metodu pro sběr dat (Reyna, 2018). Kamera je malá a nenápadná, takže nenarušuje práci skupiny, na rozdíl od situace, kdy se v její blízkosti pohybuje další osoba s kamerou v ruce.

Jako pokročilou metodu použití interaktivního prostředí pro účely přípravy budoucích učitelů lze označit aktivity University of Buffalo, na které tým výzkumníků vytvořil takové prostředí, které simuluje obtížné chování žáků ve vzdělávacím procesu - tvůrci tohoto programu označují toto prostředí za podobnou věc jako je letecký simulátor pro pilota (Anzalone, 2017). Právě takové prostředí je vhodné nejen pro budoucí učitele, ale i učitele z praxe, protože se mohou setkat s rozmanitými neobvyklými situacemi ve výuce. Nemusí se vždy jednat pouze o negativní jevy (např. o problémové chování žáků), ale také o inspiraci novými vyučovacími metodami, řízení třídy v běžných nebo i méně obvyklých aktivitách atd. V USA je užití virtuální reality při profesní přípravě součástí například přípravy studentů medicíny. Stejně jako u studentů medicíny, tak i budoucí učitelé se tímto způsobem mohou seznámit s různými situacemi a získat určité zkušenosti ze školního prostředí ještě před tím, než do tohoto prostředí půjdou pracovat.

\subsection{Simulovaná a inscenovaná výuka jako alternativa videozáznamů}

Jedním z problémů, který je v této oblasti řešen, je využitelnost videozáznamů výuky - pořízených původně např. pro výzkumné účely - pro vzdělávání 
učitelů. Z aktuálně platných právních regulací vyplývá, že autentická videa lze použít pouze pro ty účely, za nimiž byly vytvořena, což musí být výslovně uvedeno v informovaném souhlasu (srov. Sonnleitner, Prock, \& Dietl, 2018). Jelikož mnohdy není snadné takové souhlasy získat, nahrazují se autentické videozáznamy obrázkovými a textovými (popř. kombinovanými) prvky.

Každá dlouhodobější edukační činnost využívající autentické videonahrávky může tyto videonahrávky získávat dvěma základními způsoby: vyhledáváním v databázích (vlastních či veřejně dostupných, obsahujících vhodně katalogizované videozáznamy pořízené v delším časovém horizontu, v různých tř́́dách a s různými učiteli) nebo dotáčením videozáznamů v reálném čase (s žáky a učiteli, kteří jsou aktuálně k dispozici). Na rozdíl od anglicky a německy mluvících prostředí, která disponují širokou základnou a jejich veřejně dostupné databáze bývají tematicky rozmanité, české prostředí je relativně malé a pravděpodobnost nenalezení vhodného videomateriálu v databázi je velká. Na řadu pak přichází potřeba videomateriál dotočit.

Limity dotáčení autentických videomateriálů na konkrétní téma jsou obecně známé: časová, technická a administrativní náročnost. Obvyklý časově-administrativní zdlouhavý cyklus mívá zpravidla dvě jednoduché příčiny: ne vždy je pořizovateli dovoleno natáčet ve třídě, kterou si vybral, a ne vždy se ve vybrané tř́ídě děje to, co by si pořizovatel záznamu přál. $V$ nedávné době do tohoto procesu výrazně zasáhlo také nařízení GDPR (Evropská unie, 2016), které zpřísnilo nakládání s osobními daty, a tedy i s videozáznamy. Mnohem náročnější je nyní nejen pořízení nového videozáznamu, ale i použití některého staršího videozáznamu z databáze.

Možné řešení této obtížné situace nabízejí alternativní formáty, které jsou místo na videozáznamu založené na obrázcích. Takové záznamy mohou mít podobu kresleného př́běhu (sady na sebe navazujících obrázků s bublinovým rozhovorem) nebo jednoho samostatného obrázku. S prudkým rozvojem digitálních grafických možností tyto alternativní reprezentace získávají na stále větším významu - na mezinárodní konferenci matematického vzdělávání ICME-13 v Hamburku se staly výraznou součástí diskusní skupiny věnující se reprezentacím školní praxe a jejich využití v profesní přípravě učitelů. Představena zde byla tři typově odlišná na obrázcích založená prostředí: on-line simulace, vignettes a concept cartoons. 
On-line simulace od trojice autorů Webel, Connerová a Zhaová (2018) jsou jakýmsi kinoautomatem $v$ obrázkové podobě: respondent se prostřednictvím kresleného příběhu seznámí s výukovou situací (s názorem žáka, žákovským řešením) a následně vybírá z několika možností, jak by na situaci reagoval, kdyby byl v roli učitele. Po uskutečnění výběru kreslený př́iběh pokračuje zobrazením reakce žáka na zvolenou možnost. $\mathrm{V}$ závěru sekvence se respondent seznamuje se s reakcemi žáků na možnosti, které si nevybral, a reflektuje svůj výběr. Respondentovi takové prostředí nabízí možnost vidět důsledky různého učitelova jednání v jedné konkrétní situaci.

Friesenová a Kuntze (2018) využívají obrázky ve formátu, který nazývají vignettes. Respondent se zde prostřednictvím kresleného příběhu seznámí s rozhovorem učitele a několika žáků, ve kterém učitel zareagoval na otázku žáků, ale žáci jeho vysvětlení neporozuměli, a tak poskytl ještě jiné vysvětlení. Úkolem respondenta je vyjádřit se $\mathrm{k}$ přiměřenosti reakce učitele a k didaktickým modelům použitým učitelem při vysvětlování. Respondentovi takové prostředí nabízí možnost vidět různé didaktické modely v jedné konkrétní situaci.

Samková (2018, česky 2016) využívá jednotlivé obrázky ve formátu concept cartoons. Respondent se na obrázku seznámí s bublinovým rozhovorem několika žáků, kteří vyjadřují své názory na problémovou situaci vztahující se ke konkrétnímu učivu. Obsahy jednotlivých bublin mohou být představeny respondentům najednou nebo postupně $\mathrm{v}$ záměrně zvoleném pořadí. Jedna z bublin bývá prázdná. Úkolem respondenta je rozhodnout o správnosti jednotlivých žákovských názorů, zkoumat možné zdroje chyb, poskytovat rady žákům, doplňující vysvětlení a doplňující otázky a také navrhovat vlastní texty do prázdné bubliny. Respondentovi takové prostředí nabízí možnost vidět různá uvažování žáků v jedné konkrétní situaci.

Oproti videonahrávkám mají tato obrázková prostředí mnoho výhod: zcela odpadají starosti s GDPR, materiály je možné připravovat na míru (potřebným znalostem, obtížnosti, respondentovi, výukové situaci), snadněji se studují (není potřeba opakovaně zastavovat nebo vracet videozáznam, znázorněn může být výběr z delšího časového úseku videozáznamu najednou, respondent může zpracovávat informace svým vlastním tempem) a jsou lépe dostupné (při tvorbě i při využití). Ukazuje se, že při vhodném zpracování mohou obrázkové materiály působit na respondenty dokonce autentičtěji než videomateriály (Friesenová \& Kuntze, 2018). Zdánlivě jedinou výraznou 
nevýhodou je tak pouze fakt, že poskytované informace o výukové situaci nejsou kompletní ani komplexní. Ale hutnost a častá nejednoznačnost komplexních reprezentací školní praxe bývá matoucí (hlavně pro učitele na počátku profesní př́ípravy nebo pro učitele vzdělávající se v nové oblasti; Grossmann et al., 2009), a tak pro účely vzdělávání učitelů bývá vhodnější rozložit školní praxi na dílčí komponenty (např. jednání učitele, didaktické modely, uvažování žáků) a zabývat se každou z nich zvlášt'.

Další možnou alternativou videozáznamů v profesní přípravě učitelů jsou prostř̌edí založená na virtuální realitě. První zkušenosti s užitím virtuální třídy v pregraduální přípravě učitelů má například Fakulta pedagogická ZČU v Plzni (Stará, 2019). Taková prostředí jsou náročnější na tvorbu a na potřebné vybavení, ale ostatní výhody uvedené v předchozím odstavci zůstávají.

\section{Diskuse a výhledy: doporučení pro práci s videem v učitelském vzdělávání}

$\mathrm{V}$ tomto textu jsme představili vybrané domácí a zahraniční př́ístupy $\mathrm{k}$ využívání videa $\mathrm{v}$ učitelském vzdělávání. Z výzev, které se ve sledované oblasti objevují, jsme rozebírali dvě. Zaprvé to byl potenciál $360^{\circ}$ videí, který se jeví v kontextu virtuální a rozšířené reality jako značný, zadruhé to byly možnosti simulované a inscenované výuky jako alternativa videozáznamů, která se může uplatňovat tam, kde k autentickým videozáznamům chybí souhlasy s jejich použitím.

Celkově z analýzy vyplynulo, že klíčovým faktorem v profesní př́ípravě opřené o videozáznamy zůstávají aktéři - zejména vzdělavatelé učitelů a učitelé samotní. Toto potvrzuje i studie Christové a kolegů (2017), kteří se ve svém mezinárodním dotazníkovém šetření (208 vzdělavatelů učitelů, 977 kursů) zaměřují na vzdělavatele učitelů jakožto na důležitou determinantu využívání videa $\mathrm{v}$ př́ípravném $\mathrm{i}$ dalším vzdělávání učitelů. Autoři hledali vztahy mezi explanačními proměnnými (institucionální podpora / překážky, charakteristiky vzdělavatele učitelů, parametry kursu, přesvědčení vzdělavatelů učitelů a vlastnosti videa) a způsoby využití videa (sebe-reflexe, diskuse ve vrstevnické skupině, diskuse vedená vyučujícím, př́padové studie atd.). Mimo jiné formulovali závěr, že využívání videa $\mathrm{v}$ jednotlivých kursech je málo časté (v průměru 3krát v jednom kursu) a stejnorodé, co do typu videa a na něj navázaných aktivit. Ukázalo se, že výše úvazku akademiků je institucionální překážkou pro využívání videa ve větší 
míře - s vyšším počtem kursů klesala míra zapojení videa. Naopak pozitivně fungovala podpora kolegů, kteří poskytovali model úspěšné implementace videa do vzdělávání učitelů. Na rozdíl od jiných studií se nepotvrdil vztah mezi dostupností technologické podpory a využíváním videa. Studie tak kromě jiného obrací pozornost na institucionální aspekty, které ovlivňují realizaci videoprrístupů v praxi. Ty považujeme za obzvlášt' důležité v kontextu snah o systémové řešení profesního rozvoje učitelů.

Na základě výše prezentovaného přehledu informací a osobní empirie autorů tohoto textu níže formulujeme několik doporučení, která by mohla orientovat další vývoj v této oblasti.

- Konkrétní způsob využití videa v učitelském vzdělávání by měl být promyšleně vkomponován do širší koncepce přípravného nebo dalšího vzdělávání učitelů. Mělo by být zřejmé, jakou úlohu používání videí v širší koncepci plní, jaké učitelské dispozice jsou pomocí videa rozvíjeny.

- Jako vhodné se jeví vytvářet při práci s videi prŕležitosti pro spolupráci v profesních (učitelských) komunitách, aby mohlo docházet ke sdílení a rozvíjení profesních znalostí. Zajistit to lze např. zavedením on-line či off-line (moderovaných) diskusí k vybraným videím apod.

- Videa by se měla dle možností a potřeb kombinovat s dalšími formáty dat o výuce a jejích kontextech (textové či obrazové materiály, artefakty z výuky, aktérské či expertní komentáře apod.). Cílem by mělo být odzrcadlení komplexity výuky, na druhou stranu by nemělo dojít k zahlcení vhodné je proto věnovat pozornost výběru a rozvržení informací o výuce.

- S cílem podporovat u učitelů proces učení se z videí je vhodné formulovat k videím otázky a úkoly pro jejich analýzu. Jde o to, aby tyto úkoly učební proces směrovaly a podporovaly, přičemž objevování by zůstalo vyhrazeno učícím se.

- Jako prospěšné pro rozvoj didaktického (reflektivního) uvažování se jeví pojetí videa jako východiska k diskusi (spíše než vzoru k napodobení či inspirace pro vlastní výuku). Pouze sdílená zkušenost (zhlédnutí stejné výuky) může být východiskem pro tříbení společného profesního (popisného či hodnoticího) jazyka.

- 360stupňová videa představují zajímavou inovaci v přípravě budoucích učitelů i v dalším profesním rozvoji pedagogů z praxe. Je však žádoucí 
inspirovat se zahraničními zkušenostmi, které mohou pomoci překonat počáteční obtíže spojené s využíváním tohoto formátu videa.

- Největším limitem využívání videa v našich podmínkách je aktuálně komplikovaná legislativa spojená s ochranou osobních dat všech aktérů, kteří se na videu vyskytují.

Jak vidno, zájem o využívání videa v přípravném a dalším vzdělávání učitelů je dlouhodobý a problémy, které průběžně vyvstávají, jsou řešeny, at' už na základě technologického rozvoje, či modifikací př́stupu. Tento text si kladl za cíl nabídnout orientaci ve vývoji z poslední let - snad naplnil svůj účel, jakkoliv problematika zůstává otevřenou.

\section{Literatura}

Abdul Rahim, E., Duenser, A., Billinghurst, M., Herritsch, A., Unsworth, K., Mckinnon, A., \& Gostomski, P. (2012). A desktop virtual reality application for chemical and process engineering education. Proceedings $\mathrm{OzCHI}$ '12 (s. 1-8). New York: ACM Press.

Anzalone, Ch. (2017). UB's virtual reality expertise creates simulated classroom environment for aspiring teachers. Dostupné z http://www.buffalo.edu/ubnow/stories/2017/06/vrteacher-training.html

Argyriou, L., Economou, D., Bouki, V., \& Doumanis, I. (2016). Engaging immersive video consumers: Challenges regarding 360-degree gamified video applications. Proceedings of the 2 nd international workshop on virtual environments and advanced interfaces (VEAI2016), within the 15th International conference on ubiquitous computing and communications (s. 145-152). Granada, Spain: IEEE.

Billinghurst, M., \& Dünser, A. (2012). Augmented reality in the classroom. Computer, 45(7), 56-63. DOI: 10.1109/MC.2012.111

Conroy, A. (2017). The BBC and virtual reality. Dostupné z http://www.bbc.co.uk/rd/blog/201606-the-bbc-and-virtual-reality

Elmezeny, A., \& Wimmer, J. (2018). Immersive storytelling in 360-degree videos: An analysis of interplay between narrative and technical immersion. Journal of Virtual Worlds Research, 11(1), 1-13.

Evropská unie (2016). Nařízení Evropského parlamentu a Rady (EU) 2016/679 I: Obecné nařízení o ochraně osobních údajů. Dostupné online: http://eur-lex.europa.eu/eli/reg/2016/679/oj

Fernandez, C. (2002). Learning from Japanese approaches to professional development. The case of lesson study. Journal of Teacher Education, 53(5), 393-405.

Fonseca, D., \& Kraus, M. (2016). A Comparison of head-mounted and hand-held displays for $360^{\circ}$ videos with focus on attitude and behaviour change. Paper presented at Academic Mindtrek '16, Tampere, Finsko.

Friesen, M., \& Kuntze, S. (2018). Competence assessment with representations of practice in text, comic and video format. In O. Buchbinder \& S. Kuntze (Eds.), Mathematics teachers engaging with representations of practice (s. 113-130). Cham: Springer. 
Gaudin, C., \& Chaliès, S. (2015). Video viewing in teacher education and professional development: A literature review. Educational Research Review, 16, 41-67.

Gieser, S. N., Becker, E., \& Makedon, F. (2013). Using CAVE in physical rehabilitation exercises for rheumatoid arthritis. In F. Makedon (Ed.), Proceedings of the 6th International conference on pervasive technologies related to assistive environments - PETRA '13 (s. 1-4). New York: ACM.

Goodwin, C. (1994). Professional vision. American Anthropologist, 96(3), 606-633.

Grossman, P., Compton, C., Igra, D., Ronfeldt, M., Shahan, E., \& Williamson, P. (2009). Teaching practice: A cross-professional perspective. Teachers College Record, 111(9), 2055-2100.

Haluck, R. S. (2000). Computers and virtual reality for surgical education in the 21st century. Archives of Surgery, 135(7), 786.

Christ, T., Arya, P., \& Chiu, M. M. (2017). Video use in teacher education: An international survey of practices. Teaching and Teacher Education, 63, 22-35.

Janík, T., Dalehefte, I. M., \& Zehetmeier, S. (Eds.). (2019). Supporting teachers: Improving instruction. Examples of research-based teacher education. Münster: Waxmann.

Janík, T., Janíková, M., Knecht, P., Kubiatko, M., Najvar, P., Najvarová, V. (2009). Exploring different ways of using video in teacher education: Examples from CPV video web. In T. Janík, \& T. Seidel (Eds.), The power of video studies in investigating teaching and learning in the classroom (s. 207-224). Mnichov: Waxmann Publishing.

Janík, T., Minaříková, E., Haláková, Z., Kostková, K., Kubiatko, M., Píšová, M., ... Valkounová, E. (2011). Video v učitelském vzdělávání: teoretická východiska, aplikace, výzkum. Brno: Paido.

Janík, T., Minaříková, E., Píšová, M., Uličná, K., \& Janík, M. (2016). Profesní vidění učitelů a jeho rozvíjení prostřednictvím videoklubů. Brno: Masarykova univerzita.

Johnson, A., Roussos, M., Leigh, J., \& Vasilakis, C. (1998). The NICE project: Learning together in a virtual world. Dostupné z http://evlweb.eecs.uic.edu/aej/papers/vrais98.pdf

Joly, K. (2016). Videos show 360-degree campus views. University Business, 19(3), 26.

Kavanagh, S., Luxton-Reilly, A., Wünsche, B., \& Plimmer, B. (2016). Creating $360^{\circ}$ educational video: A case study. Proceedings of the 28th Australian conference on computer-human interaction (s. 34-39). New York: ACM.

Koellner, K., Jacobs, J., Borko, H., Schneider, C., Pittman, M.E., Eiteljorg, E., Bunning, K., \& Frykholm, J. (2007). The problem-solving cycle: A model to support the development of teachers' professional knowledge. Mathematical Thinking and Learning, 9(3), 273-303.

Le, Q. T., Pedro, A., \& Park, C. S. (2014). A social virtual reality-based construction safety education system for experiential learning. Journal of Intelligent \& Robotic Systems, 79(3-4), 487-506.

Lewis, C., Perry, R., \& Friedkin, S. (2013). Lesson study as action research. In S. Noffke \& B. Somekh (Eds.), The SAGE handbook of educational action research (s. 142-154). London: SAGE Publications Ltd.

Minaříková, E., \& Janík, T. (2012). Profesní vidění učitelů: od hledání pojmu k možnostem jeho uchopení. Pedagogická orientace, 22(2), 181-204.

Murata, A. (2011). Introduction: Conceptual overview of lesson study. In L. C. Hart, A. Alston, \& A. Murata (Eds.), Lesson study research and practice in mathematics education (s. 1-12). Dordrecht: Springer.

Naone, E. (2007). Virtual labor lost - MIT technology review. Dostupné z http://www. technologyreview.com/news/409147/virtual-labor-lost/ 
Pea, R. et al. (2004). The diver project: Interactive digital video repurposing. IEEE multimedia, 11(1), 54-61.

Reyna, J. (2018). The potential of 360-degree videos for teaching, learning and research. Proceedings of INTED2018 conference (s. 1448-1454). Valencia: IATED.

Roche, L., \& Gal-Petitfaux, N. (2017). Using $360^{\circ}$ video in physical education teacher education. Proceedings of the society for information technology \& teacher education international conference (s. 3420-3425). Austin: Association for the Advancement of Computing in Education.

Roth, K., Wilson, C., Taylor, J., Hvidsten, C., Stennett, B., Wickler, N., Kowalski, S., Numedahl, P., \& Bintz, J. (2015). Testing the consensus model of effective PD: Analysis of practice and the PD research terrain. Colorado Springs: BSCS.

Samková, L. (2016). Didaktické znalosti obsahu budoucích učitelů 1. stupně základní školy před studiem didaktiky matematiky. Scientia in Educatione, 7(2), 71-99.

Samková, L. (2018). Concept cartoons as a representation of practice. In O. Buchbinder \& S. Kuntze (Eds.), Mathematics teachers engaging with representations of practice (s. 71-93). Cham: Springer.

Sheikh, A., Brown, A., Evans, M., \& Watson, Z. (2016). Directing attention in 360-degree video. Paper presented at IBC 2016 Conference, Amsterdam, Nizozemsko.

Sherin, M. G. (2004). New perspectives on the role of video $n$ teacher education. In J. Brophy (Ed.), Using video in teacher education (pp. 1-27). Amsterdam: Elsevier.

Sherin, M. G. (2007). The development of teachers' professional vision in video clubs. In R. Goldman, R. Pea, B. Barron, \& S. J. Derry (Eds.), Video research in the learning sciences (s. 383-396). London: Lawrence Erlbaum Associates Publishers.

Slavík, J., Janík, T., Najvar, P., \& Knecht, P. (2017). Transdisciplinární didaktika: o učitelském sdílení znalostí a zvyšování kvality výuky např́ć obory. Brno: Masarykova univerzita.

Sonnleitner, M., Prock, S., \& Dietl, D. (2018). Die Beteiligten informieren - aber wie?: Informationsschreiben und Einwilligungserklärungen konkret. In M. Sonnleitner, S. Prock, A. Rank, \& Kirchhoff, P. (Eds.), Video- und Audiografie von Unterricht in der Lehrerinnenbildung (s. 145-173). Opladen: Verlag Barbara Budrich.

Stará, Š. (2019). Virtuální třída pomůže studentům naučit se učit. Dostupné z http://info.zcu.cz/ clanek.jsp?id=2156

Švecová, Z. (2011). Virtuální hospitace: zkušenosti z Výzkumného ústavu pedagogického v Praze. In T. Janík, E. Minaříková (Eds.), Video v učitelském vzdělávání: teoretická východiska, výzkum, aplikace (s. 94-101). Brno: MU.

Tang, A., \& Fakourfar, 0. (2017). Watching $360^{\circ}$ videos together. In Proceedings of the 20170020CHI Conference on Human Factors in Computing Systems (s. 4501-4506). New York: ACM.

Vondrová, N. (2019). Lesson study, enhanced with video-based tasks, in the education of mathematics teachers: Lesson study in the middle. In T. Janík, I. M. Dalehefte, \& S. Zehetmeier (Eds.), Supporting teachers: Improving instruction. Examples of researchbased teacher education (s. 129-151). Münster: Waxmann.

Vosmeer, M., \& Schouten, B. (2014). Interactive cinema: Engagement and interaction. In A. Mitchell, C. Fernández-Vera \& D. Thue (Eds.), International conference on interactive digital storytelling (s. 140-147). Switzerland: Springer International Publishing. 
Webel, C., Conner, K. \& Zhao, W. (2018). Simulations as a tool for practicing questioning. In 0 . Buchbinder \& S. Kuntze (Eds.), Mathematics teachers engaging with representations of practice (s. 95-112). Cham: Springer.

Wiecha, J., Heyden, R., Sternthal, E., \& Merialdi, M. (2010). Learning in a virtual world: Experience with using second life for medical education. Journal of Medical Internet Research, 12(1), 1-17.

Yamashita, Y. \& Taira, N. (2016). Presentation skills training by using a 360 degree camera. In G. Veletsianos (Ed.), Proceedings of EdMedia 2016 World conference on educational media and technology (s. 1381-1384). Vancouver: Association for the Advancement of Computing in Education.

\section{Autoři}

prof. PhDr. Mgr. Tomáš Janík, Ph.D., Masarykova univerzita, Pedagogická fakulta, Institut výzkumu školního vzdělávání, Poříčí 31, 60300 Brno, e-mail: tjanik@ped.muni.cz doc. PaedDr. Monika Černá, Ph.D., Masarykova univerzita, Pedagogická fakulta, Institut výzkumu školního vzdělávání, Pořrićí 31, 60300 Brno, e-mail: cerna@ped.muni.cz

doc. Mgr. Petr Najvar, Ph.D., Masarykova univerzita, Pedagogická fakulta, Institut výzkumu školního vzdělávání, Pořŕčí 31,603 00 Brno, e-mail: najvar@ped.muni.cz

RNDr. Libuše Samková, Ph.D., Jihočeská univerzita v Českých Budějovicích, Pedagogická fakulta, Katedra matematiky, Jeronýmova 10, 37115 České Budějovice, e-mail: Isamkova@pf.jcu.cz

Mgr. Lukáš Rokos, Ph.D., Jihočeská univerzita v Českých Budějovicích, Pedagogická fakulta, Katedra biologie, Jeronýmova 10, 37115 České Budějovice, e-mail: Lrokos@pf.jcu.cz

PhDr. Jan Petr, Ph.D., Jihočeská univerzita v Českých Budějovicích, Pedagogická fakulta, Katedra biologie, Jeronýmova 10, 37115 České Budějovice, e-mail: janpetr@pf.jcu.cz

\section{Video in Teacher Education: Approaches and Challenges}

Abstract: This study surveys current national and international approaches to the use of video in teacher education. It depicts the continuity of the development showing that the video recordings, which were originally created for research purposes, have gradually been implemented in initial and in-service teacher education to a more considerable extent. The paper is divided into four parts. The first part discusses the context of teacher education, in which video is used, and introduces ten approaches that are documented in the relevant literature. The second part offers answers to the following four questions: (1) In what way is a particular approach integrated in the conception of teacher education / professional development support? (2) What aims / purposes are found in the rationale of individual approaches? (3) What components constitute a whole and how do they function? (4) What specific activities (those of 
users, tutors or designers) are implemented within the framework of a particular approach and what are they intended to develop? The third part of the study offers a discussion of the challenges, which have emerged in the field; however, they have not been reflected in the relevant literature yet. It mainly concerns the implementation of virtual reality and 360-degree video, the potential of on-line simulations, vignettes, and concept cartoons representing alternatives to video, and ethical issues related to the use of video in teacher education, etc. The fourth part of the study attempts to answer the question whether it is possible to formulate certain guidelines that might direct the development in this field.

Keywords: video in teacher education, initial teacher education, professional development, instruction 